\title{
MANUSCRIPT AND TYPESCRIPT MATERIAL RELATING TO HOWELLS'S THE SON OF ROYAL LANGBRITH
}

\author{
BY DAVID J. BURROWS
}

Assistant Professor of English, Douglass College, Rutgers University

$7 \mathrm{HE}$ recent announcement of a full-scale edition of the writings of William Dean Howells under the aegis of the Modern Language Association's Center for Editions of American Authors places new emphasis on the importance of Howells's manuscript holdings. While no complete manuscripts of the major novels are known to be in existence, the Rutgers University Library is fortunate in having purchased in 1946 two fragments of manuscript and typescript of a large portion of one of Howells's late important novels, The Son of Royal Langbrith, which I am at present editing for the forthcoming edition. Because of the relative scarcity of known Howells's manuscript material, especially of his better fiction, these fragments will prove invaluable in the process of tracing Howells's techniques of composition and revision; evident in these fragments, for instance, are three separate stages of revision prior to serial publication.

The two fragments, which overlap, consist of an autograph manuscript and two kinds of typescript. The autograph manuscript is made up of 54 sheets, and comprises the text of the last quarter of the novel with some omissions (roughly pp. 282-369 of the first edition. $)^{1}$ These sheets are numbered 3 I6-322, 326-332, 337-348, $35 \mathrm{I}-353,356-368,376,38 \mathrm{I}, 385-386,397-403$, and 4I3. The second fragment, I 32 sheets of typescript, corresponds to slightly less than the last half of the novel (pp. 209-369). These sheets are numbered 227-4I 3 (lacking 230, 254-258, 260-262, and 267).

\footnotetext{
${ }^{1} \mathrm{My}$ task in the ordering of these materials has been greatly simplified by Professor John K. Reeves's painstaking examination of the manuscript in connection with his "The Literary Manuscripts of W. D. Howells: A Descriptive Finding List," Bulletin of the New York Public Library, LXII (June and July, 1958), 267-278, 350$36_{3}$, and a supplementary list, LXV (Sept., 196I), 465-476.
} 
Printers' directions on one of these sheets make evident the fact that this latter fragment was used as copy for the serial publication of the novel in The North American Review (January through August, I904).

There are two kinds of typescript: 90 legal-size sheets of regular type and 42 blue typewriter-size sheets of the italic type from the typewriter which Mark Twain had sold to Howells (and about which they carried on a running joke for years after the transaction). These latter sheets, numbered 323-325, 333, 334-5-6 (one sheet), $349-350,354-355,369-375,377-380,382-384,387-396$, and 404$4 \mathrm{I} 2$, correspond exactly to the sheets missing from the fragment of autograph manuscript; and, as John K. Reeves deduced, ${ }^{2}$ the autograph sheets and blue italic type sheets must have been given to a typist to prepare the final copy for The North American Review; the typist probably had instructions not to retype the already typed pages (from the Twain typewriter). The legal-size typed sheets represent, therefore, a later version of the material in the autograph manuscript sheets.

The autograph manuscript and both kinds of typescript were revised by Howells; but since the manuscript and legal-size typescript show much less revision than the pages of italic typescript, one is led to agree with Reeves that the italic typescript represents the earliest state within the materials at hand; the sheets of autograph manuscript were probably substituted for extensively revised pages of italic typescript, which were then discarded.

The Rutgers's holdings are further enriched by five autograph letters from Howells to D. A. Munro, assistant editor of The North American Review, directly concerning the serial publication of The Son of Royal Langbrith. These letters, dated from Sept. 3, I 903 to Feb. 25, 1904, reveal much of interest. They show, for instance, that Howells was finishing his revision of the novel during September and October, I903, at Kittery Point, Maine, which leads Reeves to suggest that perhaps Howells did not bring his typewriter with him from New York; thus explaining the sheets of longhand revision. ${ }^{3}$

\footnotetext{
${ }^{2}$ In a letter to the Rutgers University Library, dated March 25, 1954, and filed with the manuscript.

${ }^{3}$ Ibid.
} 
The letters also provide information concerning Howells's procedures for sending copy to the publisher and reading proof: on Oct. IO, I903, he tells Munro that he is sending him the first installment of the novel (for the January number of the Revierw); on Oct. 29, he says he is sending the second installment and returning the proof of the first. In another letter, dated Feb. 23, 1904, he tells Munro that the proof for the fifth installment will have to be sent to him before he leaves for England in March, in order for it to be ready for the May number. He says, too, that he would be glad to receive proof for the three remaining parts as soon as possible. It is evident, then, that the last four parts were completed and in Munro's hands in February, even though they were not scheduled for publication until May through August. Probably Howells sent the last half of the novel so far in advance of publication in order to be able to sail in March. In any event, it is these last four parts, possibly sent to Munro as one package, which are extant.

From the letters, one can trace also Howells's procedure for arriving at the final title of the novel. On Sept. 3, 1903 Howells tells Munro that the title is not yet chosen, but that he had sent to Colonel Harvey, editor of the Review, a "distracting" list of possible titles, including "After this the Judgment" and "Acquiescence"; Colonel Harvey had preferred "Outlawed," but Howells states that adjectival and participial titles do not please him. In reply to this letter, Munro must have suggested that the word "legacy" be used in the title, for Howells writes to Munro on Sept. I2 of the coincidence of having just carefully looked up the meaning of "legacy" so as to call the novel "The Legacy of Royal Langbrith." "That," he states, "ought to settle it." But on Oct. io he informs Munro that he has decided on "The Son of Royal Langbrith," which is "not only fairly descriptive" but will also, he adds facetiously, "make it outsell 'Lady Rose's Daughter'!" (Mrs. Humphry Ward's number-one best-seller of 1903 ). It is in that "gaudy hope" that he closes the letter. 